\title{
Chemical Constituents from the Stems of Ecdysanthera rosea
}

\author{
Chang-Wei Song $\cdot$ Paul-Keilah Lunga $\cdot$ \\ Xu-Jie Qin • Gui-Guang Cheng • Ya-Ping Liu • \\ Xiao-Dong Luo
}

Received: 10 April 2014 / Accepted: 29 May 2014/Published online: 2 November 2014

(C) The Author(s) 2014. This article is published with open access at Springerlink.com

\begin{abstract}
One new eudesmane sesquiterpenoid (1) named ecdysantherol A and two new benzene derivatives ecdysantherols B (2) and C (3), together with five known benzene derivatives (4-8) were isolated from the stems of Ecdysanthera rosea. The structures of the new compounds were elucidated by extensive spectroscopic methods and X-ray diffraction. The known compounds were identified by the comparison of their spectroscopic data with reported literature data. Compound 1 showed moderate antibacterial activity against the Providensia smartii with MIC value of $12.5 \mu \mathrm{g} / \mathrm{mL}$.
\end{abstract}

Keywords Ecdysanthera rosea $\cdot$ Sesquiterpenoid $\cdot$ Phenolic glycoside $\cdot$ Absolute configuration

\section{Introduction}

The Ecdysanthera comprises 15 species. Of which Ecdysanthera rosea is mainly distributed in tropical and

Electronic supplementary material The online version of this article (doi:10.1007/s13659-014-0041-3) contains supplementary material, which is available to authorized users.

C.-W. Song · P.-K. Lunga · X.-J. Qin · G.-G. Cheng ·

Y.-P. Liu $(\square) \cdot$ X.-D. Luo $(\square)$

State Key Laboratory of Phytochemistry and Plant Resources in West China, Kunming Institute of Botany, Chinese Academy of Sciences, Kunming 650201, People's Republic of China e-mail: liuyaping@mail.kib.ac.cn

X.-D. Luo

e-mail:xdluo@mail.kib.ac.cn

C.-W. Song · X.-J. Qin · G.-G. Cheng

University of Chinese Academy of Sciences, Beijing 100049,

People's Republic of China

P.-K. Lunga

Laboratory of Phytobiochemistry and Medicinal Plants Study, Department of Biochemistry, Faculty of Science, University of Yaoundé 1, P.O. Box 812, Yaoundé, Cameroon subtropical areas of Asia and used as a traditional Chinese medicinal plant for the treatment of sore throat, chronic nephritis and trauma in China [1]. Terpenoids, benzene derivatives, steroids and their glycosides have been previously reported in this plant, they include three terpenoids and one steroid saponin with cytotoxic activities [2-12].

Given that the chemical constituents isolated from $E$. rosea are still limited and the existing bioactivity research of them are not related to its medicinal use directly. This attracted our attention to searching for more novel natural products from it. The present chemical investigation led to the isolation of three new compounds (1-3) (Fig. 1), and five known compounds: manglieside $\mathrm{D}$ (4) [13] erythro-guaiacylglycerol- $\beta-O-4^{\prime}$-coniferyl alcohol (5) [14], (+)-(7S,8R)-guaiacylglycerol (6) [15], isocopoletin (7) [16], evofolin-B (8) [17] from this plant. In addition, preliminary test showed that compound $\mathbf{1}$ was a moderate antibacterial constituent against Providensia smartii with MIC value of $12.5 \mu \mathrm{g} / \mathrm{mL}$, but a weak antibacterial constituent against Enterococcus faecalis and Staphylococcus aureus with MIC value of $50 \mu \mathrm{g} / \mathrm{mL}$ and $50 \mu \mathrm{g} / \mathrm{mL}$ respectively. In this paper, we report the isolation and structure elucidation of the new compounds. 
Fig. 1 Chemical structures of compounds 1-4 and the standard chemicals

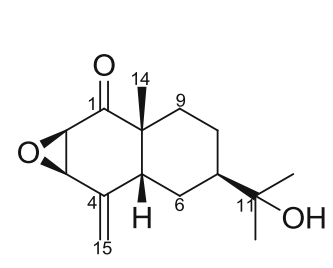

1

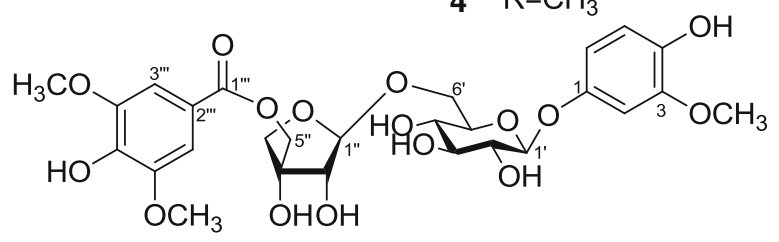<smiles>[3H]c1cc(O)cc(OC)c1</smiles>

3-methoxy-5-methylpehnol<smiles>CCc1ccc(O)c(OC)c1</smiles>

4-ethyl-2-methoxyphenol

\section{Results and Discussion}

The molecular formula of compound $\mathbf{1}$ was determined to be $\mathrm{C}_{15} \mathrm{H}_{22} \mathrm{O}_{3}$ by the HREIMS at $m / z 250.1579[\mathrm{M}]^{+}$(calcd. $250.1569)$, indicating five degrees of unsaturation. The ${ }^{13} \mathrm{C}$ NMR and DEPT spectroscopic data exhibited 15 carbon signals for three methyls at $\delta_{\mathrm{C}} 26.8(\mathrm{q}), 27.6(\mathrm{q}), 21.4(\mathrm{q})$, four methylenes at $\delta_{\mathrm{C}} 22.9(\mathrm{t}), 22.6(\mathrm{t}), 32.7(\mathrm{t}), 117.0(\mathrm{t})$, four methines at $\delta_{\mathrm{C}} 57.8(\mathrm{~d}), 59.4(\mathrm{~d}), 37.7$ (d), $43.2(\mathrm{~d})$, and four quaternary carbons at $\delta_{\mathrm{C}} 143.2(\mathrm{~s}), 46.9$ (s), 71.7 (s), $\delta_{\mathrm{C}} 209.7$ (s). Except for one ketone and a pair of double bond, it's suggested that there should be a tricyclic structure in compound 1 to fit the three degrees of unsaturation. The ${ }^{1} \mathrm{H}$ NMR spectrum displayed two olefinic protons at $\delta_{\mathrm{H}}$ $5.68(1 \mathrm{H}, \mathrm{d}, J=2.1 \mathrm{~Hz}, \mathrm{H}-15 \mathrm{a}), 5.36(1 \mathrm{H}, \mathrm{d}, J=2.1 \mathrm{~Hz}$, $\mathrm{H}-15 \mathrm{~b}$ ), in accordance with a terminal double bond at $\delta_{\mathrm{C}}$ $117.0(\mathrm{t})$ in ${ }^{13} \mathrm{C}$ NMR spectrum which was supported by the HSQC experiment. The protons at $\delta_{\mathrm{H}} 3.42(1 \mathrm{H}$, d, $J=3.9 \mathrm{~Hz}, \mathrm{H}-2)$ and $\delta_{\mathrm{H}} 3.99(1 \mathrm{H}, \mathrm{d}, J=3.9 \mathrm{~Hz}, \mathrm{H}-3)$ with the same coupling constant indicated an epoxy moiety which was also supported by the ${ }^{1} \mathrm{H}-{ }^{1} \mathrm{H}$ COSY correlation between them (Fig. 2). The HMBC correlations from the singlet methyl signal at $\delta_{\mathrm{H}} 1.21(3 \mathrm{H}, \mathrm{s}, \mathrm{H}-14)$ to $\delta_{\mathrm{C}} 209.7$ $(\mathrm{C}-1), \delta_{\mathrm{C}} 37.7(\mathrm{C}-5), \delta_{\mathrm{C}} 32.7(\mathrm{C}-9), \delta_{\mathrm{C}} 46.9$ (C-10); from the proton at $\delta_{\mathrm{H}} 2.73(\mathrm{H}-5)$ to $\delta_{\mathrm{C}} 143.2(\mathrm{C}-4), \delta_{\mathrm{C}} 117.0(\mathrm{C}-$ $15), \delta_{\mathrm{C}} 43.2(\mathrm{C}-7), \delta_{\mathrm{C}} 22.9(\mathrm{C}-6)$ and from the terminal methyl signals at $\delta_{\mathrm{H}} 1.15(3 \mathrm{H}, \mathrm{s}, \mathrm{H}-12)$ and $\delta_{\mathrm{H}} 1.15(3 \mathrm{H}, \mathrm{s}$, $\mathrm{H}-13)$ to $\delta_{\mathrm{C}} 71.7(\mathrm{C}-11)$ and $\delta_{\mathrm{C}} 43.2(\mathrm{C}-7)$, together with the ${ }^{1} \mathrm{H}-{ }^{1} \mathrm{H}$ COSY correlations between $\delta_{\mathrm{H}} 1.63$ (H-6a) and $\delta_{\mathrm{H}} 2.73(\mathrm{H}-5), \delta_{\mathrm{H}} 1.66(\mathrm{H}-7)$ proposed an eudesmane sesquiterpenoid skeleton of compound $\mathbf{1}$. In addition, single-crystal X-ray diffraction (Fig. 2) using anomalous scattering of $\mathrm{CuK} \alpha$ radiation (CCDC 1006467) revealed the absolute configuration of $\mathbf{1}$ as $(2 R, 3 S, 5 S, 7 S, 10 S)-2,3-$ epoxy-eudesm-4(15)-en-11-ol-1-one. Thus, compound $\mathbf{1}$ was elucidated as shown in Fig. 1, and named ecdysantherol A.

Compound 2 was isolated as a yellow powder. Its molecular formula $\mathrm{C}_{25} \mathrm{H}_{32} \mathrm{O}_{11}$ was deduced by the positive HR-ESIMS $\mathrm{m} / z$ 531.1841 $[\mathrm{M}+\mathrm{Na}]^{+}$. The NMR of 2 were very similar to the known compound manglieside $\mathrm{D}$ [13]. By comparison of the NMR data in literatures, the same structure segments of a 1,3,5-trisubstituted aromatic ring, a disubstituted $E$-configuration double bond and a sugar unit were confirmed $[18,19]$. The major difference was that compound 2 possessed a different $1^{\prime}, 3^{\prime}, 4^{\prime}, 5^{\prime}$-tetrasubstituted aromatic ring, in which a methoxy group at $\mathrm{C}-3^{\prime}$ of manglieside $\mathrm{D}$ was replaced by a hydroxy group and this could be confirmed by its molecular formula and different proton signals at $\delta_{\mathrm{H}} 6.81(1 \mathrm{H}, \mathrm{d}, J=1.8 \mathrm{~Hz}$, $\left.\mathrm{H}-2^{\prime}\right), \quad \delta_{\mathrm{H}} 6.83\left(1 \mathrm{H}, \mathrm{d}, J=1.8 \mathrm{~Hz}, \mathrm{H}-6^{\prime}\right)$. Therefore, compound 2 was elucidated as shown in Fig. 1, and named ecdysantherol B Fig. 1.

Confusingly, one literature neglected coupling constant and assigned same coupling pattern as $3-\mathrm{OCH}_{3}$ and $4-\mathrm{OH}$ substituted aromatic ring, because NOE correlation of methoxyl proton with only one aromatic proton $(\mathrm{C}-2)$ was observed in ROESY spectrum, which deduced a substituted aromatic carbon (C-4) [20]. Interestingly, same NOE correlation pattern was observed in ROESY spectrum of $\mathbf{2}$. Then, ${ }^{1} \mathrm{H}$ NMR spectral data of compound 2 were further collected in different solvent, and the result indicated same coupling pattern without large coupling constant to meet Ortho-proton in aromatic ring. To further confirmed our assignment, we ordered standard chemicals of 3-methoxy5-methylpehnol (CAS NO. 3209-13-0), and 4-ethyl-2methoxyphenol (CAS NO. 2785-89-9), and ${ }^{1} \mathrm{H}$ NMR spectral data of two compounds were record in DMSO- $d 6$. 
Fig. 2 Selected ${ }^{1} \mathrm{H}-{ }^{1} \mathrm{H}$ COSY

$(-)$, HMBC correlations $(\rightarrow)$

and the X-ray structure of $\mathbf{1}$
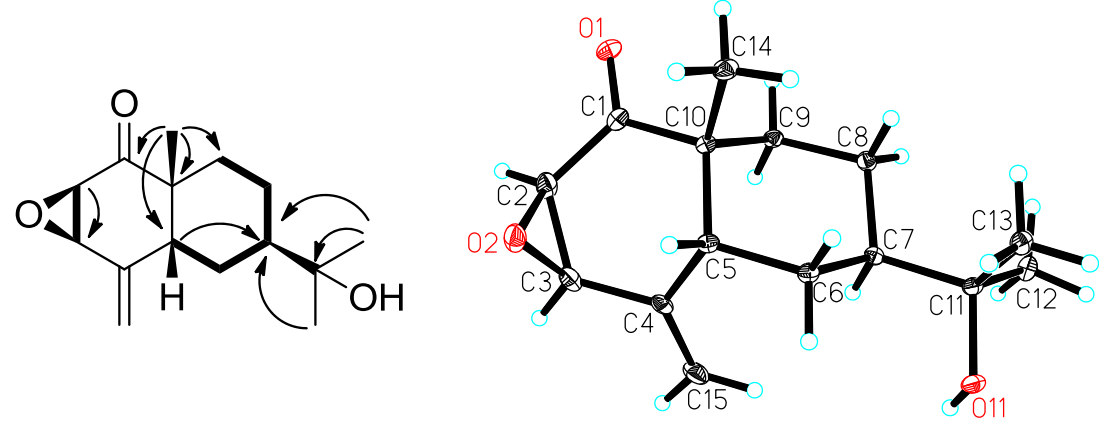

The same coupling pattern of compound $\mathbf{2}$ and 3-methoxy5-methylpehnol unambiguously confirmed 1,3,5-trisubstituted aromatic ring and proposed that no observation of NOE correlation between $-\mathrm{OCH}_{3}$ with both aromatic protons $(\mathrm{H}-2$ and $\mathrm{H}-4)$ was not sufficient reason for 1,3,4trisubstituted assignment. Besides, chemical shift of $-\mathrm{OH}$ in DMSO- $d 6$ might be a characteristic for 3-methoxy-4hydroxy substituted (ca $\delta_{\mathrm{H}} 8.7$ ) and 3-methoxy-5-hydroxy substituted (ca $\delta_{\mathrm{H}} 9.3$ ) in aromatic ring.

Compound 3 was isolated as a yellow powder. The molecular formula $\mathrm{C}_{27} \mathrm{H}_{34} \mathrm{O}_{16}$ was deduced by HRESIMS at $\mathrm{m} / z 614[\mathrm{M}+\mathrm{Na}]^{+}$. Detailed analysis of NMR data indicated that $\mathbf{3}$ had a similar structure to that of the known compound previously reported, [21] except for the substituent groups on the aromatic ring. By comparison of its NMR data with those reported in literature, the signals at $\delta_{\mathrm{H}} 7.34\left(1 \mathrm{H}, \mathrm{s}, \mathrm{H}-3^{\prime \prime \prime}\right), 7.34\left(1 \mathrm{H}, \mathrm{s}, \mathrm{H}-7^{\prime \prime \prime}\right)$ showed that $\mathbf{3}$ had a different 1,3,4,5-tetra-substituted aromatic ring. In addition, the HMBC correlations from $\delta_{\mathrm{H}} 3.77(3 \mathrm{H}, \mathrm{s}$, $\mathrm{OMe})$ to 149.1 (C-3) suggested it had another different 1,2,4-tri-substituted aromatic ring with the known compound. The above observations indicated that compound $\mathbf{3}$ was an analogue of the known compound. Furthermore, the detailed 2D NMR spectroscopic data revealed the position of the hydroxy groups and methoxy groups in compound $\mathbf{3}$. Thus, compound $\mathbf{3}$ was elucidated as shown in Fig. 1, and named ecdysantherol $\mathrm{C}$.

\section{Experimental Section}

\subsection{General Experimental Procedures}

Optical rotations were obtained with a Jasco P-1020 Automatic Digital Polariscope. UV spectrum was measured with a Shimadzu UV2401PC in $\mathrm{MeOH}$ solution. IR spectra $(\mathrm{KBr})$ were obtained on a Bruker tensor-27 infrared spectrophotometer. ${ }^{1} \mathrm{H},{ }^{13} \mathrm{C}$, and $2 \mathrm{D}$ NMR spectra were recorded on a Bruker AM-400, a DRX-500 NMR and an Avance III 600 spectrometer with TMS as internal standard. MS data were obtained on a Waters Autospec
Premier P776 for HREI. An APEX DUO (Bruker) instrument was used for the single crystal X-ray diffraction. Column chromatography (CC) was performed on Silica gel (200-300 mesh, Qingdao Marine Chemical Ltd., Qingdao, People's Republic of China) and RP-18 gel (20-45 $\mu \mathrm{m}$, Fuji Silysia Chemical Ltd., Tokyo, Japan). Fractions were monitored by TLC (GF 254, Qingdao Haiyang Chemical Co., Ltd., Qingdao, People's Republic of China), and spots were visualized by $10 \% \mathrm{H}_{2} \mathrm{SO}_{4}$-ethanol reagent.

\subsection{Plant Material}

The dried stems of E. rosea were collected from Xishuangbanna Autonomous Prefecture, Yunnan Province, People's Republic of China, and identified by Jingyun Cui of Xishuangbanna Botanic Garden. A voucher specimen (Cui 200811-03) has been deposited at the Herbarium of Kunming Institute of Botany, Chinese Academy of Sciences.

\subsection{Extraction and Isolation}

The air-dried and smashed stems of E. rosea $(10 \mathrm{~kg})$ were extracted with $\mathrm{MeOH}$ three times at room temperature. After in vacuum pump evaporation of the solvent, the combined crude extract was suspended in $\mathrm{H}_{2} \mathrm{O}$ and extracted with ethyl acetate three times. The EtOAc fraction $(129.0 \mathrm{~g})$ was eluted with gradient mixtures of $\mathrm{CHCl}_{3}-$ $\mathrm{MeOH}(100: 1 \rightarrow 1: 1)$ on silica gel column to yield 5 fractions [Fr.A (38.5 g), Fr.B (13 g), Fr.C (14 g), Fr.D $(9 \mathrm{~g})$, Fr.E $(18 \mathrm{~g})]$. Fraction B (13 g) was isolated by Sephadex LH-20 and repeated silica gel column to yield compound $1(11 \mathrm{mg})$. Fraction D $(9 \mathrm{~g})$ was chromatographed over Sephadex LH-20 (MeOH), MPLC $(\mathrm{MeOH}-$ $\left.\mathrm{H}_{2} \mathrm{O}\right)$ and HPLC $\left(\mathrm{MeCN}-\mathrm{H}_{2} \mathrm{O}\right)$ to provide compound 5 $(7 \mathrm{mg})$. Fraction E $(18 \mathrm{~g})$ was subjected to the Sephadex LH-20, eluted with $\mathrm{MeOH}-\mathrm{H} 2 \mathrm{O}$ (1:1) and chromatographed over $\mathrm{RP}^{-\mathrm{C}_{18}}$ gel $(\mathrm{MeOH}-\mathrm{H} 2 \mathrm{O})$ to afford compounds $2(6 \mathrm{mg}), 3(5 \mathrm{mg}), 4(17 \mathrm{mg}), \mathbf{6}(14 \mathrm{mg}), \mathbf{7}$ $(14 \mathrm{mg})$ and $8(8 \mathrm{mg})$.

Compound 1; colorless needle crystal; $[\alpha]_{\mathrm{D}}^{21.5}+67.0$ (c $0.1, \mathrm{MeOH})$; IR (KBr) $v_{\max } 3360,1635 \mathrm{~cm}^{-1} ;{ }^{1} \mathrm{H}$ 
Table 1 NMR Data of 1-3 ( $\delta$ in ppm and $J$ in $\mathrm{Hz}$ )

\begin{tabular}{|c|c|c|c|c|c|c|c|c|}
\hline \multirow[t]{2}{*}{ No. } & \multicolumn{2}{|l|}{$1^{\mathrm{a}}$} & \multirow[t]{2}{*}{ No. } & \multicolumn{2}{|l|}{$2^{\mathrm{b}}$} & \multirow[t]{2}{*}{ No. } & \multicolumn{2}{|l|}{$3^{\mathrm{b}}$} \\
\hline & $\delta_{\mathrm{H}}$ & $\delta_{\mathrm{C}}$ & & $\delta_{\mathrm{H}}$ & $\delta_{\mathrm{C}}$ & & $\delta_{\mathrm{H}}$ & $\delta_{\mathrm{C}}$ \\
\hline 1 & & $209.7 \mathrm{~s}$ & 1 & & $133.1 \mathrm{~s}$ & 1 & & $152.7 \mathrm{~s}$ \\
\hline 2 & $3.42(\mathrm{~d}, 3.9)$ & $57.8 \mathrm{~d}$ & 2 & 6.68 (br s) & $114.1 \mathrm{~d}$ & 2 & $6.69(\mathrm{~d}, 2.6)$ & $103.8 \mathrm{~d}$ \\
\hline 3 & $3.99(\mathrm{~d}, 3.9)$ & $59.4 \mathrm{~d}$ & 3 & & $148.4 \mathrm{~s}$ & 3 & & $149.1 \mathrm{~s}$ \\
\hline 4 & & $143.2 \mathrm{~s}$ & 4 & 6.63 (br s) & $115.7 \mathrm{~d}$ & 4 & & $142.9 \mathrm{~s}$ \\
\hline 5 & 2.73 (br s) & $37.7 \mathrm{~d}$ & 5 & & $145.4 \mathrm{~s}$ & 5 & $6.65(\mathrm{~d}, 8.6)$ & $116.0 \mathrm{~d}$ \\
\hline 6 & $\begin{array}{l}2.13(\mathrm{~m}) \\
1.63(\mathrm{~m})\end{array}$ & $22.9 \mathrm{t}$ & 6 & 6.63 (br s) & $122.7 \mathrm{~d}$ & 6 & $6.54(\mathrm{dd}, 8.6,2.6)$ & $109.8 \mathrm{~d}$ \\
\hline 7 & $1.66(\mathrm{~m})$ & $43.2 \mathrm{~d}$ & 7 & $2.90(\mathrm{~m})$ & $38.1 \mathrm{t}$ & $1^{\prime}$ & $4.68(\mathrm{~d}, 7.3)$ & $103.6 \mathrm{~d}$ \\
\hline 8 & $\begin{array}{l}1.64(\mathrm{~m}) \\
1.34(\mathrm{~m})\end{array}$ & $22.6 \mathrm{t}$ & 8 & $4.01(\mathrm{~m})$ & $42.3 \mathrm{~d}$ & $2^{\prime}$ & $3.40(\mathrm{~m})$ & $74.9 \mathrm{~d}$ \\
\hline 9 & $\begin{array}{l}1.37(\mathrm{~m}) \\
1.33(\mathrm{~m})\end{array}$ & $32.7 \mathrm{t}$ & 9 & $\begin{array}{l}3.69(\mathrm{dd}, 10.4,6.9) \\
3.63(\mathrm{dd}, 10.4,6.3)\end{array}$ & $66.6 \mathrm{t}$ & $3^{\prime}$ & $3.41(\mathrm{~m})$ & $77.9 \mathrm{~d}$ \\
\hline 10 & & $46.9 \mathrm{~s}$ & $1^{\prime}$ & & $135.6 \mathrm{~s}$ & $4^{\prime}$ & $3.33(\mathrm{~m})$ & $71.5 \mathrm{~d}$ \\
\hline 11 & & $71.7 \mathrm{~s}$ & $2^{\prime}$ & $6.81(\mathrm{~d}, 1.8)$ & $113.2 \mathrm{~d}$ & $5^{\prime}$ & $3.51(\mathrm{~m})$ & $76.7 \mathrm{~d}$ \\
\hline 12 & $1.15(\mathrm{~s})$ & $26.8 \mathrm{q}$ & $3^{\prime}$ & & $150.9 \mathrm{~s}$ & $6^{\prime}$ & $\begin{array}{l}4.03(\mathrm{~d}, 11.0) \\
3.62(\mathrm{dd}, 11.0, \\
6.2)\end{array}$ & $68.4 \mathrm{t}$ \\
\hline 13 & $1.15(\mathrm{~s})$ & $27.6 \mathrm{q}$ & $4^{\prime}$ & & $144.9 \mathrm{~s}$ & $1^{\prime \prime}$ & $5.02(\mathrm{~d}, 2.1)$ & $110.5 \mathrm{~d}$ \\
\hline 14 & $1.21(\mathrm{~s})$ & $21.4 \mathrm{q}$ & $5^{\prime}$ & & $138.1 \mathrm{~s}$ & $2^{\prime \prime}$ & $3.98(\mathrm{~d}, 2.1)$ & $78.7 \mathrm{~d}$ \\
\hline 15 & $\begin{array}{l}5.68(\mathrm{~d}, 2.1) \\
5.36(\mathrm{~d}, 2.1)\end{array}$ & $117.0 \mathrm{t}$ & $6^{\prime}$ & $6.83(\mathrm{~d}, 1.8)$ & $118.5 \mathrm{~d}$ & $3^{\prime \prime}$ & & $79.0 \mathrm{~s}$ \\
\hline & & & $7^{\prime}$ & $6.49(\mathrm{~d}, 15.8)$ & $131.4 \mathrm{~d}$ & $4^{\prime \prime}$ & $\begin{array}{l}4.08(\mathrm{~d}, 9.8) \\
3.86(\mathrm{~d}, 9.8)\end{array}$ & $75.0 \mathrm{~d}$ \\
\hline & & & $8^{\prime}$ & $6.23(\mathrm{dt}, 15.8,5.6)$ & $129.4 \mathrm{~d}$ & $5^{\prime \prime}$ & $\begin{array}{l}4.40(\mathrm{~d}, 11.3) \\
4.33(\mathrm{~d}, 11.3)\end{array}$ & $67.8 \mathrm{t}$ \\
\hline & & & $9^{\prime}$ & $4.19(\mathrm{dd}, 5.5,1.2)$ & $63.6 \mathrm{t}$ & $1^{\prime \prime \prime}$ & & $167.8 \mathrm{~s}$ \\
\hline & & & $1^{\prime \prime}$ & $4.57(\mathrm{~d}, 7.8)$ & $107.0 \mathrm{~d}$ & $2^{\prime \prime \prime}$ & & $121.0 \mathrm{~s}$ \\
\hline & & & $2^{\prime \prime}$ & $3.50(\mathrm{~m})$ & $75.5 \mathrm{~d}$ & $3^{\prime \prime \prime}$ & $7.34(\mathrm{~s})$ & $108.3 \mathrm{~d}$ \\
\hline & & & $3^{\prime \prime}$ & $3.38(\mathrm{~m})$ & $77.9 \mathrm{~d}$ & $4^{\prime \prime \prime}$ & & $148.8 \mathrm{~s}$ \\
\hline & & & $4^{\prime \prime}$ & $3.45(\mathrm{~m})$ & $70.7 \mathrm{~d}$ & $5^{\prime \prime \prime}$ & & $141.9 \mathrm{~s}$ \\
\hline & & & $5^{\prime \prime}$ & $3.19(\mathrm{~m})$ & $78.3 \mathrm{~d}$ & $6^{\prime \prime \prime}$ & & $148.8 \mathrm{~s}$ \\
\hline & & & $6^{\prime \prime}$ & $\begin{array}{l}3.78(\mathrm{~m},) \\
3.73(\mathrm{~m})\end{array}$ & $61.9 \mathrm{t}$ & $7^{\prime \prime \prime}$ & $7.34(\mathrm{~s})$ & $108.3 \mathrm{~d}$ \\
\hline & & & -OMe & $3.73(\mathrm{~s})$ & $56.3 \mathrm{q}$ & -OMe & $3.77(\mathrm{~s})$ & $56.3 \mathrm{q}$ \\
\hline & & & & & & -OMe & $3.86(\mathrm{~s})$ & $56.8 \mathrm{q}$ \\
\hline & & & & & & $-\mathrm{OMe}$ & $3.86(\mathrm{~s})$ & $56.8 \mathrm{q}$ \\
\hline
\end{tabular}

a Measured in chloroform- $d_{3}$

b Measured in methanol- $d_{4}$

(400 MHz) and ${ }^{13} \mathrm{C}$ NMR $(100 \mathrm{MHz})$ data $(\mathrm{MeOH})$, see Table 1, HREIMS $m / z, 250.1579$ (calcd for $\mathrm{C}_{15} \mathrm{H}_{22} \mathrm{O}_{3}$, 250.1569).

Compound 2; yellow, amorphous powder; $[\alpha]_{\mathrm{D}}^{21.3}+$ 28.3 (c 0.1, MeOH); UV (MeOH) $\lambda_{\max }(\log \varepsilon) 245.6$ (4.12), 203.0 (4.65) nm; IR (KBr) $v_{\max } 3425,2985,1029 \mathrm{~cm}^{-1} ;{ }^{1} \mathrm{H}$ (400 MHz) and ${ }^{13} \mathrm{C}$ NMR (100 MHz) data, see Table 1,
HREIMS $m / z \quad 531.1851$ (calcd for $\mathrm{C}_{25} \mathrm{H}_{32} \mathrm{O}_{11} \mathrm{Na}$, 531.1842).

Compound 3; yellow, amorphous powder; $[\alpha]_{\mathrm{D}}^{22.3}-64.1$ (c 0.15, MeOH); UV (MeOH) $\lambda_{\max }(\log \varepsilon) 284.2$ (4.05), 202.8 (4.57) nm; IR (KBr) $v_{\max } 3431,1049 \mathrm{~cm}^{-1} ;{ }^{1} \mathrm{H}(400 \mathrm{MHz})$ and ${ }^{13} \mathrm{C}$ NMR (100 MHz) data, see Table 1 , HREIMS $\mathrm{m} / z$ 637.1754 (calcd for $\mathrm{C}_{27} \mathrm{H}_{34} \mathrm{O}_{16} \mathrm{Na}, 637.1745$ ). 


\subsection{Antimicrobial assays}

The microorganisms used in the antimicrobial assay were obtained from the American Type Culture Collection (ATCC). They included three bacteria strains: E. faecalis ATCC 10541, S. aureus ATCC 25922 and Providensia smartii ATCC29916. The MIC values of the compounds were determined by the broth microdilution method in 96-well microtitre. The 96-well plates were prepared by dispensing into each well $100 \mu \mathrm{L}$ of Mueller-Hinton broth for bacteria. The test substances were initially prepared in $10 \%$ DMSO in broth medium at $400 \mu \mathrm{g} / \mathrm{mL}$ for compounds or $50 \mu \mathrm{g} / \mathrm{mL}$ for the reference antibiotics, gentamycin. A volume of $100 \mu \mathrm{L}$ of each test sample was added into the first wells of the microtitre plate (whose wells were previously loaded with $100 \mu \mathrm{L}$ of broth medium). Serial two-fold dilutions of the test samples were made and $100 \mu \mathrm{L}$ of bacterial inoculum standardized at $10^{6} \mathrm{CFU} / \mathrm{mL}$ were added. This gave final concentration ranges from 100 to $0.781 \mu \mathrm{g} / \mathrm{mL}$ for the compounds and 12.5 to $0.097 \mu \mathrm{g} /$ $\mathrm{mL}$ for reference substance. The plates were sealed with parafilm, then agitated with a plate shaker to mix their contents and incubated at $35^{\circ} \mathrm{C}$ for $24 \mathrm{~h}$.

MICs were determined upon addition of $50 \mu \mathrm{L}(0.2 \mathrm{mg} /$ mL) $p$-iodonitrotetrazolium chloride (INT, Sigma-Aldrich, South Africa). Viable bacteria reduced the yellow dye to a pink color. The MIC corresponded to the lowest well concentration where no color turbidity change was observed, indicating no growth of microorganism. All tests were performed in triplicates.

\subsection{Crystallographic Data of $\mathbf{1}$}

$\mathrm{C}_{15} \mathrm{H}_{22} \mathrm{O}_{3}, \quad M=250.33$, orthorhombic, $a=5.85670(10)$ $\AA, b=11.1899(2) \AA, c=19.6555(3) \AA, \alpha=90.00^{\circ}$, $\beta=90.00^{\circ}, \gamma=90.00^{\circ}, V=1288.14(4) \AA^{3}, T=100(2)$ $\mathrm{K}$, space group $P 212121, Z=4, \mu(\mathrm{CuK} \alpha)=0.706 \mathrm{~mm}^{-1}$, 7204 reflections measured, 2162 independent reflections $\left(R_{\text {int }}=0.0345\right)$. The final $R_{1}$ values were $0.0346(I>$ $2 \sigma(I))$. The final $w R\left(F^{2}\right)$ values were $0.1028(I>2 \sigma(I))$. The final $R_{1}$ values were 0.0347 (all data). The final $w R\left(F^{2}\right)$ values were 0.1029 (all data). The goodness of fit on $F^{2}$ was 1.130. Flack parameter $=0.1(2)$. The Hooft parameter is $0.06(6)$ for 852 Bijvoet pairs. The crystal structure of compound 1 was solved by direct method SHELXS-97 and expanded using the difference Fourier techniques, refined by the program SHLXL-97 and the full-matrix leastsquares calculations. Crystallographic data for the structure of compound $\mathbf{1}$ have been deposited with the Cambridge Crystallographic data centre (deposition no. CCDC
1006467). Copies of these data can be obtained free of charge via www.ccdc.cam.ac.uk.

Acknowledgments This project was supported by the National Natural Science Foundation of China (81225024), the National Science and Technology Support Program of China (2013BAI11B02).

Conflict of Interest The authors declare no conflict of interest.

Open Access This article is distributed under the terms of the Creative Commons Attribution License which permits any use, distribution, and reproduction in any medium, provided the original author(s) and the source are credited.

\section{References}

1. Y. Jiang, B.T. Li, Flora of China, vol. 63 (Science Press, Beijing, 1977), p. 234

2. P. Luger, M. Weber, N.X. Dung, P.T. Ky, L. Chinh, Acta. Crystallogr. 52, 1574-1576 (1996)

3. D.K. Chu, T.C. Le, T.K. Pham, Tap. Chi. Duoc. Hoc. 4, 13-16 (1997)

4. P. Luger, M. Weber, X.D. Nguyen, T.K. Pham, Cryst. Res. Technol. 33, 325-332 (1998)

5. T.K. Pham, T.C. Le, Tap. Chi. Duoc. Hoc. 5, 14-16 (1997)

6. C. Le, T. Nguyen, T.K. Pham, H. Trinh, X.D. Nguyen, P. Luger, Tap. Chi. Duoc. Hoc. 4, 16-17 (1995)

7. X.D. Zhu, Q.H. Zhang, F. Wang, Y.J. Ye, Zhongcaoyao 42, 237-240 (2011)

8. K.F. Huang, M.L. Sy, J.S. Lai, J. Chin. Chem. Soc. 37, 187-189 (1990)

9. X.D. Zhu, Q.H. Zhang, L. Kong, F. Wang, S.D. Luo, Fitoterapia 81, 906-909 (2010)

10. F.Q. Xu, H.Y. Liu, C.X. Chen, H.M. Zhong, Chem. Nat. Compd. 44, 308-316 (2008)

11. F.Q. Xu, H.Y. Liu, F. Teng, C.X. Chen, H.M. Zhong, Tianran Chanwu Yanjiu Yu Kaifa 19, 365-368 (2007)

12. X.D. Zhu, G.S. Wu, J.Y. Xiang, H.R. Luo, S.D. Luo, H.M. Zhu, Fitoterapia 82, 632-636 (2011)

13. V.K. Phan, D.T. Mai, V.D.T. Le, H.T. Nguyen, N.H. Nguyen, Chem. Pharm. Bull. 56, 1270-1275 (2008)

14. L. Lyia, P.S. Navindra, J. Agric. Food. Chem. 58, 11673-11679 (2010)

15. D.G. Marina, F. Antonio, M. Pietro, P. Lucio, Synth. Commun. 28, 3693-3700 (1998)

16. W.J. Liang, Q.Y. Ma, H.Z. Jiang, J. Zhou, J. Pang, Y.X. Zhao, Chin. Tradit. Herb. Drugs 42, 1271-1275 (2011)

17. T.S. Wu, J.H. Yeh, P.L. Wu, Phytochemistry 40, 121-124 (2011)

18. G. Fang, C.P. Tang, Y. Yang, Helv. Chim. Acta 91, 1023-1030 (2008)

19. Q.A. Zheng, M. Xu, C.R. Yang, D. Wang, H.Z. Li, H.T. Zhu, Y.J. Zhang, Nat. Prod. Bioprospect. 2, 111-116 (2012)

20. S. Britta, S. Silke, H. Josef, K. Nasser, H. Sonja, M. Christa, J. Nat. Prod. 65, 1479-1485 (2002)

21. W. Tsutomu, N. Yoshimi, N. Tadataka, Chem. Pharm. Bull. 54, 14-20 (2006) 